\title{
Cloning and Expression of meta-Cleavage Enzyme (CarB) of Carbazole Degradation Pathway from Pseudomonas stutzeri
}

\author{
Ariane Leites Larentis ${ }^{1,2^{*}}$, Tito Lívio Moitinho Alves ${ }^{1}$ and Orlando Bonifácio Martins ${ }^{2}$ \\ ${ }^{1}$ Laboratório de Bioprocessos; Programa de Engenharia Química - COPPE; Centro de Tecnologia; Universidade \\ Federal do Rio de Janeiro; Cidade Universitária; Ilha do Fundão; C. P. 68502; 21945-970; \\ ariane@peq.coppe.ufrj.br; Rio de Janeiro-RJ -Brasil. ${ }^{2}$ Laboratório de Biologia Molecular; Instituto de Bioquímica \\ Médica; Centro de Ciências da Saúde; Universidade Federal do Rio de Janeiro; Cidade Universitária; Ilha do \\ Fundão; 21941-590; Rio de Janeiro -RJ -Brasil
}

\begin{abstract}
In this work, the 1082bp PCR product corresponding to carBaBb genes that encode the heterotetrameric enzyme 2'aminobiphenyl-2,3-diol 1,2-dioxygenase (CarB), involved in the Pseudomonas stutzeri ATCC 31258 carbazole degradation pathway, was cloned using the site-specific recombination system. Recombinant clones were confirmed by PCR, restriction enzyme digestion and sequencing. CarB dioxygenase was expressed in high levels and in active form in Escherichia coli BL21-SI using the His-tagged expression vector PDEST ${ }^{T M} 17$ and salt induction for $4 h$.
\end{abstract}

Key words: Carbazole, 2'-aminobiphenyl-2,3-diol dioxygenase, HOADA, heterologous gene expression, petroleum denitrogenation, biodegradation

\section{INTRODUCTION}

Carbazole and its dibenzopyrrole derivatives are recalcitrant heterocyclic aromatic compounds and potentially pollutants, commonly found in petroleum and other fossil fuels (Benedik et al., 1998). The presence of these nitrogenated compounds, of which carbazole is one of the major species, is characteristic of Brazilian oils and deleterious to the refining process. The coupling of nitrogenated compounds biodegradation pathways to the expensive hydrotreating processes used for $\mathrm{N}$ and $\mathrm{S}$ removal (HDN and HDS, respectively) is a strategy of current great biotechnological interest. Due to the high selectivity and mild conditions of most bioprocesses, they could be envisaged as alternative to hydrotreating processes that employ high temperature and pressure, as well as alter other petroleum constituents (Benedik et al., 1998). Some carbazole-degrader bacteria, as Pseudomonas sp., able to grow in carbazole as sole carbon and nitrogen source, have been described in the literature. The general carbazole degradation pathway to anthranilic acid involves two different dioxygenases (carbazole and 2'aminobiphenyl-2,3-diol) and a hydrolase, whose genes are present in an $6 \mathrm{~kb}$ operon into a megaplasmid found in those bacteria (Sato et al. , $1997^{\mathrm{a}, \mathrm{b}}$ ).

The second pathway enzyme, 2'-aminobiphenyl2,3-diol 1,2-dioxygenase (CarB), is an extradiol dioxygenase that catalyzes the meta-cleavage of the cathecolic ring of the compound 2'aminobiphenyl-2,3-diol to produce 2-hydroxy-6oxo-6-(2'-aminophenyl)-hexa-2,4-dienoic acid (HOADA). This enzyme is encoded by both $\mathrm{carBa}$

\footnotetext{
*Author for correspondence
} 
and $c a r B b$ genes and is probably an $\alpha_{2} \beta_{2^{-}}$ heterotetramer. The catalytic site is composed by a ferrous ion present in a conserved LigB-domain in the subunit CarBb (Iwata et al., 2003). CarBa did not present significant homologies to other nucleotide or amino acid sequences (Sato et al., $\left.1997^{\mathrm{a}}\right)$. The schematic meta-cleavage reaction is presented in Fig. 1.

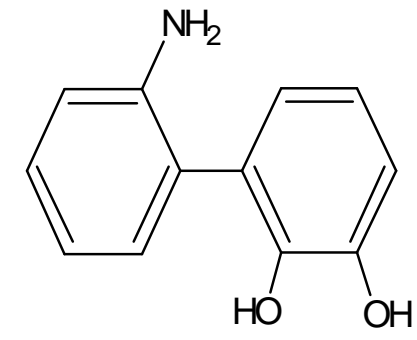

2'-aminobiphenyl-2,3-diol

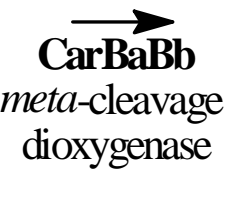

2-hidroxy-6-oxo-6-(2'aminophenyl)-

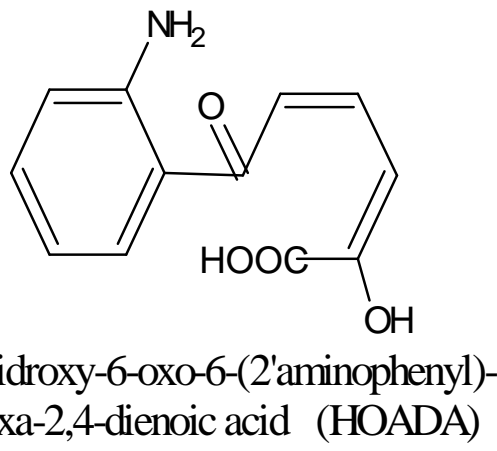

Figure 1 - Meta-cleavage catalyzed by CarB (2'-aminobiphenyl-2,3-diol 1,2dioxygenase). 2'-aminobiphenyl-2,3-diol is the product of carbazole conversion by carbazole dioxygenase (CarA).

Recently, the meta-cleavage enzymes from Pseudomonas sp. CA10 and LD2 were cloned and expressed (Sato et al., 1997 ${ }^{\mathrm{a}}$, Iwata et al., 2003; Riddle et al., 2003). The recombinant DNA technology permits to enhance protein concentration and to control the expression levels, which is indispensable for obtaining high concentrations of biocatalysts, proteins with biological activities and with high economic values for biotechnological applications. The use of enzymes that can tolerate extreme conditions of temperature, pressure, solvents and $\mathrm{pH}$ is strategic for bioremediation and biorefining processes. However, no homologue carbazole biodegradation enzymes were found in thermophilic microorganisms deposited in GenBank (Larentis et al., 2002). A promising approach is the expression of these mesophilic enzymes into extremophilic hosts. For instance, the two-component enzyme $\mathrm{CarBaBb}$ from Sphingomonas sp. GTIN11 was expressed in the thermophile Thermus thermophilus (Park et al., 2004). Nevertheless, the expression of heterologous genes in thermophiles is incipient, and more studies are required to improve the expression levels.

In this work, the 2'-aminobiphenyl-2,3-diol 1,2dioxygenase from $P$. stutzeri was cloned using the site-specific recombination system and expressed in high levels in E. coli. This is a versatile cloning approach because it could provide high efficiency and fidelity cloning, independent of vector function or host (Hartley et al., 2000). Thus, it could be visualized as a cloning system for expression in thermophiles.

\section{MATERIALS AND METHODS}

\section{$P$. stutzeri total DNA extraction}

Genes encoding 2'-aminobiphenyl-2,3-diol 1,2dioxygenase were obtained from $P$. stutzeri ATTC 31258 (Hisatsuka and Sato, 1994) total DNA. The genomic DNA was extracted with Wizard $^{\circledR} \mathrm{SV}$ Genomic DNA Purification System (Promega).

\section{PCR}

$C a r B a$ and $c a r B b$ genes were amplified by PCR with $P$. stutzeri genomic DNA as template. Primers were made as described for $P$. resinovorans CA10 deposited in GenBank (Sato et al., 1997 ${ }^{\mathrm{a}, \mathrm{b}}$ ) and adding CACC sequence on direct primer 5', before start codon for entry vector ligation. PCR was performed using a PTC100 thermal cycler (MJ Research) with Platinum ${ }^{\circledR} P f x$ DNA Polymerase (Invitrogen). Salts ( $\mathrm{KCl}$ and $\mathrm{MgCl}_{2}$ ), dNTPs and primers concentrations, as well 
as the cycling conditions, were used as described in Shepherd and Lloyd-Jones (1998). PCR product was analyzed by $1 \%$ agarose gel electrophoresis and eluted with ultrapure water from $1 \%$ low melt agarose gel with phenol/chloroform in the final concentration of $10 \mathrm{ng} / \mu \mathrm{L}$ to clone into TOPO/GATEWAY ${ }^{\mathrm{TM}}$ system (Invitrogen).

\section{Cloning of genes encoding CarB}

The 1082bp PCR product of $C a r B a B b$ genes was ligated to the kanamycin-resistant 2580bp Entry Vector pENTR/D-TOPO ${ }^{\circledR}$ (Invitrogen), through the overhang sequence GTGG ligation to primer complementary sequence CACC by the action of topoisomerase (Heyman et al., 1999). This vector presents the $100 \mathrm{bp}-a t t \mathrm{~L} 1$ and $a t t \mathrm{~L} 2$ recombination sites to produce $\mathrm{T} 7$ promoter His-tagged Expression Vector by the action of LR Clonase (Invitrogen) in the reaction with $125 \mathrm{bp}-$ att $\mathrm{R} 1$ and attR2 sites presented in the 6354bp plasmid pDEST $^{\text {TM }} 17$ (Invitrogen), that presents ampicillin resistance (Hartley et al., 2000). His-tagged recombinant proteins are used for purification in $\mathrm{Ni}$ columns. The cloning strategy employed for $c a r B a B b$ using topoisomerase and site-specific recombination is shown in Fig. 2.

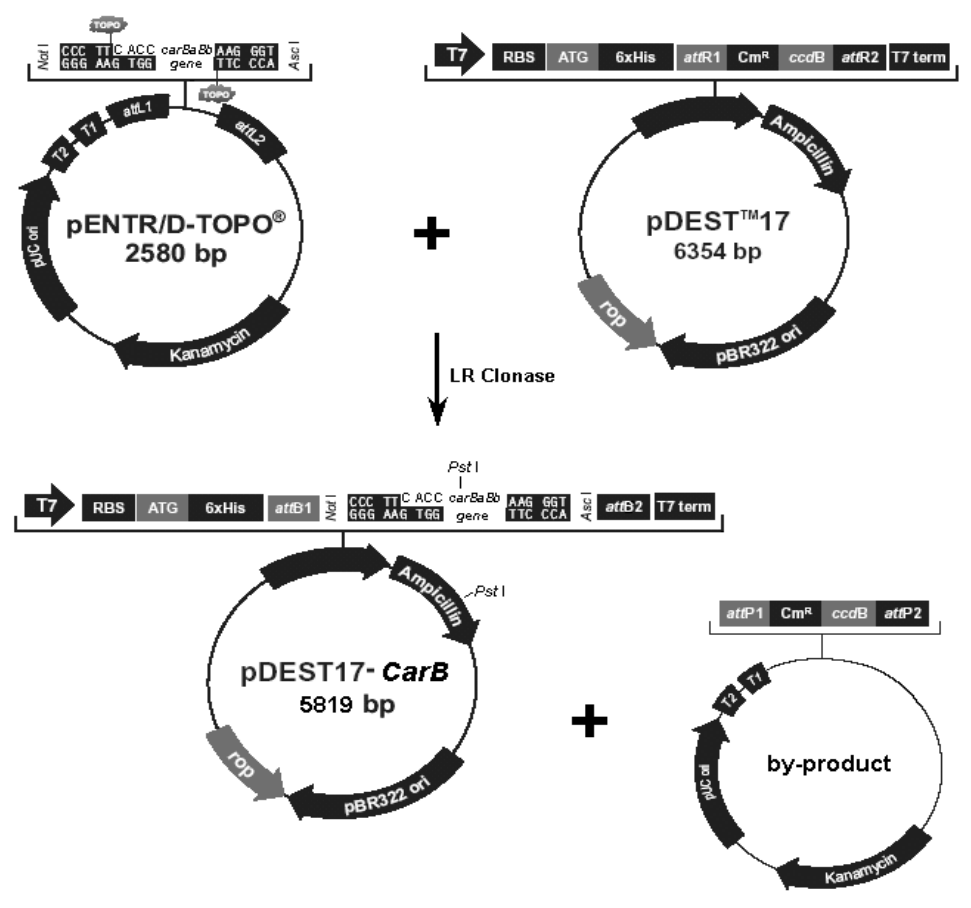

Figure 2 - Cloning strategy employed for $c a r B a B b$ using topoisomerase and site-specific recombination.

Plasmid DNA was prepared from E. coli cells by alkaline lysis (Sambrook et al., 1989). The cloning confirmations were made by PCR (conditions described in previous section), plasmid restriction with endonucleases NotI (GC'GGCCGC) for Entry Vector ligated to $C a r B a B b$ and PstI (CTGCA'G) for Expression Vector, and by sequencing. Restriction endonucleases were used according to the manufacturer's instructions (Amersham Biosciences). Construction of plasmids was analyzed by agarose gel electrophoresis. DNA sequencing was performed using Cycle Sequency Big Dye Terminators in ABI 377 DNA Sequencer (Applied Biosystems).

\section{E. coli transformation}

E. coli DH10B was used as host for plasmid DNA cloning and sequencing. E. coli BL21-SI was used for salt-inducible protein expression under the control of T7 promoter and protease deficient for minimizing heterologous protein degradation (Bhandari and Gowrishankar, 1997). Cells were previously submitted to ultrapure water washes (Dower et al., 1988) and stored at $-70^{\circ} \mathrm{C}$. Hosts 
transformations were made by electroporation by a $5 \mathrm{~ms}$ electric discharge with $1.80 \mathrm{kV}, 25 \mu \mathrm{F}$ and $200 \Omega$ using Gene Pulser ${ }^{\circledR}$ II (Bio-Rad) and selection with the appropriate antibiotic medium plates, standing overnight at $37^{\circ} \mathrm{C}$.

\section{Cells cultivations}

E. coli $\mathrm{DH} 10 \mathrm{~B}$ was cultivated at $37^{\circ} \mathrm{C}$ in $\mathrm{LB}$ $(\mathrm{NaCl} 1 \%$, bactotryptone $1 \%$ and yeast extract $0.5 \%$ ) and BL21-SI was grown in the same medium lacking $\mathrm{NaCl}$ (LBON) with the appropriate antibiotics (kanamycin or ampicillin at final concentrations of 50 or $100 \mu \mathrm{g} / \mathrm{mL}$, respectively).

\section{CarB expression}

E. coli BL21-SI harboring recombinant His-tagged Expression Vector was cultivated in $10 \mathrm{~mL}$ LBON medium at $37^{\circ} \mathrm{C}$ until reached the absorbance 0.8 at $600 \mathrm{~nm}$. Then, CarB expression was induced with $0.3 \mathrm{M} \mathrm{NaCl}$ and incubated for $4 \mathrm{~h} .1 \mathrm{~mL}$ samples (before salt induction and with $4 \mathrm{~h}$ ) were harvested and the pellets were stored at $-20^{\circ} \mathrm{C}$.

\section{Preparation of cell extract}

The pellets from $1 \mathrm{~mL}$ samples were resuspended in GET (glucose $50 \mathrm{mM}$, EDTA $10 \mathrm{mM}$ and Tris$\mathrm{HCl} 25 \mathrm{mM}$ ), sonicated and submitted to total protein concentration measurement by Bradford method (Bradford, 1976), with bovine serum albumin as standard.

\section{SDS-PAGE}

18\% SDS-Polyacrilamide Gel Electrophoresis was performed with $20 \mu \mathrm{g}$ of cell extract in a Bio-Rad apparatus. Gel was stained with Coomassie brilliant blue R-250.

\section{Determination of activity}

CarB activity for the 2,3-dihydroxybiphenyl (analogous to 2'-aminobiphenyl-2,3-diol) were analyzed by spraying the E. coli BL21-SI colonies with recombinant plasmids on plates and visually observing the formation of the yellow metabolite 2-hydroxy-6-oxo-6-phenylhexa-2,4-dienoic acid (HOPDA) (Sato et al., 1997 ; Riddle et al., 2003; Park et al., 2004).

\section{RESULTS AND DISCUSSION}

A 1082bp gene was amplified by PCR using a proofreading DNA polimerase, corresponding to the expected size for $c a r B a B b$ (Fig. 3). This PCR product was cloned into $\mathrm{pENTR/D-TOPO}{ }^{\circledR}$ vector and the selected kanamycin-resistant colonies were analyzed by PCR and restriction enzyme digestion. From 12 selected colonies, 8 were confirmed as positive for $c a r B a B b$ gene product ligation.

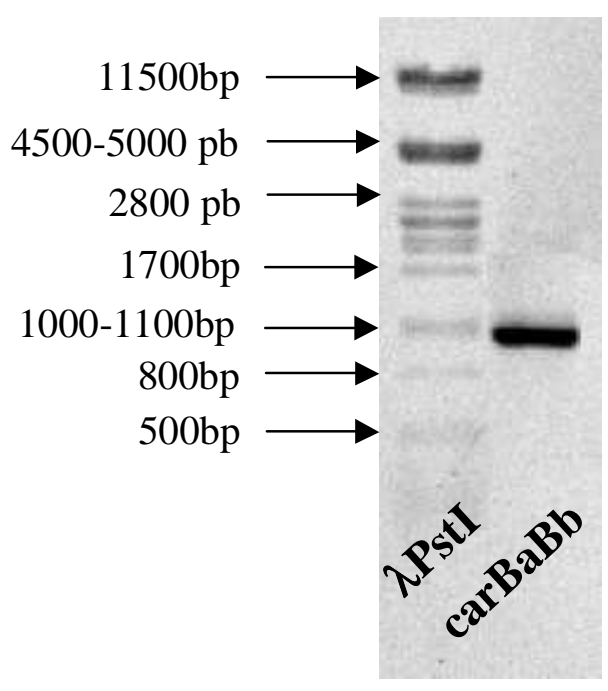

Figure 3 - Agarose gel (1\%) of PCR carBaBb amplification product ( 1100bp confirmed with $\lambda$ PstI size ladder). 


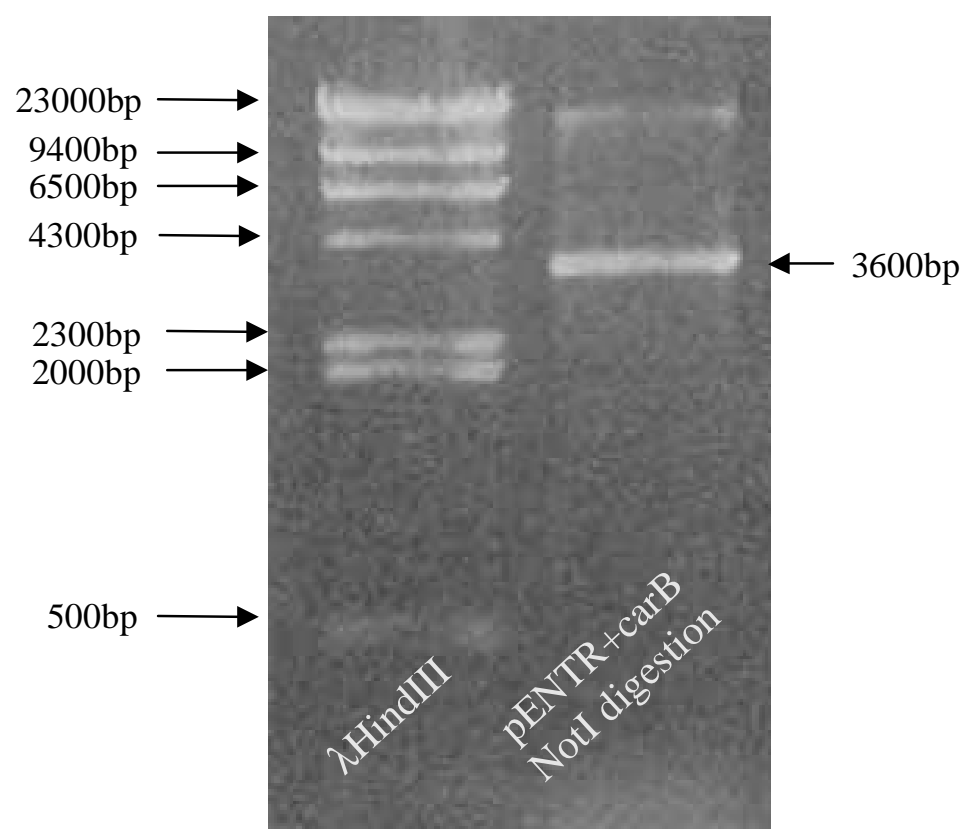

Figure 4 - 1\% agarose gel with $\sim 3600 \mathrm{bp}$ corresponding to restriction of positive $\mathrm{pENTR} / \mathrm{D}-\mathrm{TOPO}^{\circledR}+\operatorname{carBaBb}$ clones with $N o t \mathrm{I}$ (size confirmed with $\lambda$ HindIII DNA ladder).

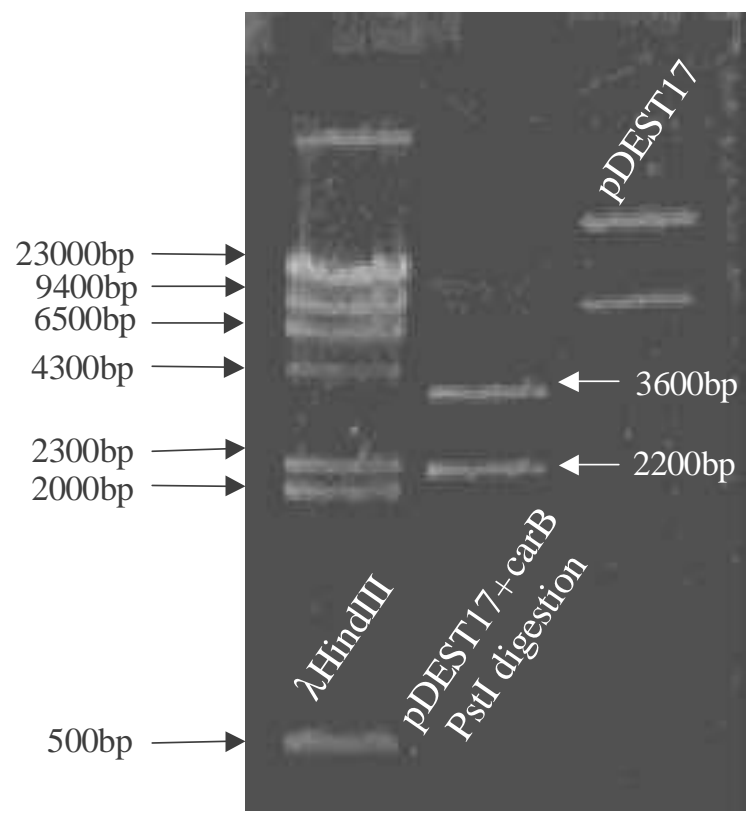

Figure 5 - $1 \%$ agarose gel with PstI restriction of constructed CarB expression plasmid (two bands of $3.6 \mathrm{~kb}$ and $2.2 \mathrm{~kb}$ confirmed with $\lambda$ HindIII DNA size ladder). 
These positive clones were confirmed by the 1082bp band amplification by PCR and also by plasmid linearization with NotI in the position 673 of pENTR/D-TOPO ${ }^{\circledR}$ vector, producing a $3600 \mathrm{bp}$ fragment in agarose gel (Fig. 4).

A confirmed plasmid $\mathrm{pENTR/D-TOPO}{ }^{\circledR}$ ligated to $c a r B a B b$ gene was chosen for sequencing and submission to recombinant reaction and production of expression vector. The sequencing confirmed the $c a r B a B b$ gene. Ampicillin resistance selected the transformant colonies and 12 of them were analyzed by PCR and PstI restriction (the enzyme site is presented in position 3116 of pDEST ${ }^{\mathrm{TM}} 17$ and 181 of $c a r B a B b$ gene). PstI restriction analysis confirmed the production of two bands: $3600 \mathrm{bp}$ and 2200bp for all selected clones, as well as the confirmation of the $1082 \mathrm{bp}$ amplification by PCR. These results confirmed the high specificity of recombinases reaction, as $100 \%$ of analyzed colonies were positive, as indicated in the literature (Hartley et al., 2000). The PstI restriction for the 5819bp pDEST17+carB plasmid is shown in Fig. 5.
The proteins were expressed by salt induction for 4h. SDS-PAGE showed two bands of 29 and $10 \mathrm{kDa}$, corresponding to $\mathrm{CarBb}$ and $\mathrm{CarBa}$ expected protein sizes, respectively (Fig. 6). Expression results showed the enrichment of the target protein in the cell extract and tests on plates confirmed the enzymatic activity. Expression levels obtained for site-specific recombination system were similar to those obtained for wellknown pUC cloning system (Iwata et al., 2003). Therefore, the site-specific recombination system was confirmed to be a simple and rapid two-step fidelity cloning process for proteins overexpression, instead of the use of traditional restriction endonucleases and ligase cloning. It also takes advantage of the versatility of the recombination system to transfer the cloned gene into different vectors and hosts, as extremophiles, which is very interesting for biotechnological applications.

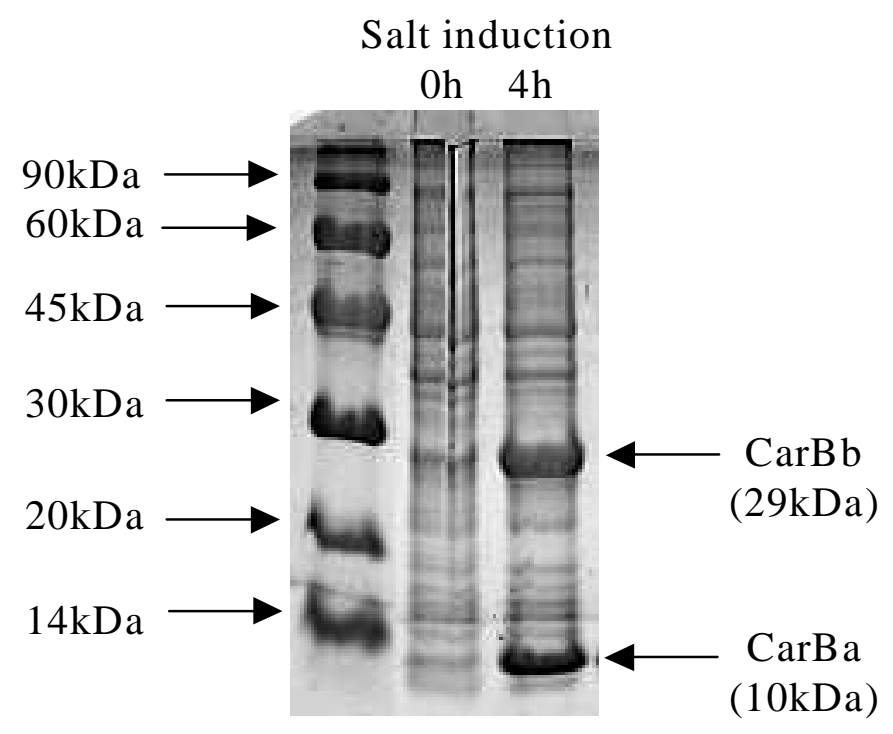

Figure 6 - SDS-PAGE of CarBa and CarBb obtained by BL21-SI cell extract samples without and with $4 \mathrm{~h}$ of salt induction. 
Further steps would include the use of cloning system to obtain all carbazole degradation pathway enzymes and to improve enzymatic expression by scaling-up the growth of recombinant cells, allowing applications in nitrogen biodegradation.

\section{ACKNOWLEDGEMENTS}

We thank $\mathrm{CNPq}$ (Conselho Nacional de Desenvolvimento Científico e Tecnológico) and CTPetro/FINEP-N ${ }^{\circ} 21.01 .0278 .00$ for supporting this work. We thank to Laboratório de Biologia Molecular and also Núcleo de Estudos de Genoma Johanna Döbenreiner/UFRJ staff for technical assistance.

\section{RESUMO}

Carbazol e seus derivados são compostos nitrogenados aromáticos, presentes comumente em petróleo e potencialmente poluentes. A rota de biodegradação de carbazol a ácido antranílico em Pseudomonas sp. é composta por três enzimas responsáveis, respectivamente, pelas reações de dioxigenação angular, meta-clivagem e hidrólise. A segunda enzima da rota, 2'-aminobifenil-2,3-diol 1,2-dioxigenase ( $\mathrm{CarB})$, codificada por dois genes (carBa e carBb), é um heterotetrâmero com atividade catalítica na quebra do anel catecol do susbtrato na posição meta. Neste trabalho, foi clonado o produto de PCR de $1082 \mathrm{pb}$ correspondente aos genes carBaBb da bactéria degradadora de carbazol Pseudomonas stutzeri ATCC 31258. A estratégia de clonagem empregada foi a de recombinação sítio-específica e a construção dos plasmídeos foi confirmada por PCR, digestão com enzima de restrição e seqüenciamento. A enzima ativa foi expressa em altas concentrações em vetor pDEST $^{\mathrm{TM}} 17$ com cauda de histidina e promotor T7 em Escherichia coli BL21-SI com indução por $\mathrm{NaCl}$ durante $4 \mathrm{~h}$.

\section{REFERENCES}

Benedik, M. J.; Gibbs, P. R.; Riddle, R. R. and Willson, R. C. (1998), Microbial denitrogenation of fossil fuels. T. Biotechnol., 16 : (9), 390-395.
Bhandari, P. and Gowrishankar, J. (1997), An Escherichia coli host strain useful for efficient overproduction of cloned gene products with $\mathrm{NaCl}$ as the inducer. J. Bacteriol., 179, 4403-4406.

Bradford, M. M. (1976), A rapid and sensitive method for the quantification of microgram quantities of protein utilizing the principle of protein-dye binding. Anal. Biochem., 72, 248-254.

Dower, W. J.; Miller, J. F. and Ragdale, C. W. (1988), High efficiency transformation of $E$. coli by high voltage electroporation. Nucl. Acids Res., 16 : (13), 6127-6145.

Hartley, J. L.; Temple, G. F. and Brasch, M. A. (2000), DNA Cloning Using In Vitro Site-Specific Recombination. Genome Res., 10, 1788-1795.

Heyman, J. A.; Cornthwaite, J.; Foncerrada, L.; Gilmore, J. R.; Gontang, E.; Hartman, K. J.; Hernandez, C. L.; Hood, R.; Hull, H. M.; Lee, W. Y.; Marcil, R.; Marsh, E. J.; Mudd, K. M.; Patino, M. J.; Purcell, T. J.; Rowland, J. J.; Sindici, M. L. and Hoeffler, J. P. (1999), Genome-Scale Cloning and Expression of Individual Open Reading Frames Using Topoisomerase I-Mediated Ligation. Genome Res., 9, 383-392.

Hisatsuka, K. and Sato, M. (1994), Microbial Transformation of Carbazole to Anthranilic Acid by Pseudomonas stutzeri. Biosci. Biotech. Biochem., 58 : (1), 213-214.

Iwata, K.; Nojiri, H.; Shimizu, K.; Yoshida, T.; Habe, H. and Omori, T. (2003), Expression, Purification, and Characterization of 2'-Aminobiphenyl-2,3-diol 1,2-dioxygenase from Carbazole-degrader Pseudomonas resinovorans Strain CA10. Biosci. Biotechnol. Biochem., 67 : (2), 300-307.

Larentis, A. L.; Almeida, R. V.; Martins, O. B. and Alves, T. L. M. (2002), Estudo da Clonagem e Expressão dos Genes para Degradação de Carbazol de Pseudomonas sp. em Escherichia coli: Resultados de Bioinformática. Presented at Colóquio Anual de Engenharia Química/PEQ-COPPE/UFRJ, 5-6 Dec, Rio de Janeiro, Brasil.

Park, H. S.; Kayser, K. J.; Kwak, J. H. and Kilbane II, J. J. (2004), Heterologous gene expression in Thermus thermophilus: beta-galactosidase, dibenzothiophene monooxygenase, PNB carboxy esterase, 2-aminobiphenyl-2,3-diol dioxygenase, and chloramphenicol acetyl transferase. J. Ind. Microbiol. Biotechnol. 31 : (4), 189-197.

Riddle, R. R.; Gibbs, P. R.; Willson, R. C. and Benedik, M. J. (2003), Recombinant carbazole-degrading strains for enhanced petroleum processing. J. Ind. Microbiol. Biotechnol., 30, 6-12.

Sambrook, J.; Fritsch, E. F. and Maniatis, T. (1989), Molecular cloning: a laboratory manual, $2^{\text {nd }}$ ed. New York : Cold Spring Harbor Laboratory, Cold Spring Harbor. 
Sato, S. I.; Ouchiyama, N.; Kimura, T.; Nojiri, H.; Yamane, H. and Omori, T. $\left(1997^{\mathrm{a}}\right)$, Cloning of Genes Involved in Carbazole Degradation of Pseudomonas sp. Strain CA10: Nucleotide Sequences of Genes and Characterization of meta-Cleavage Enzymes and Hydrolase. J. Bacteriol., 179 : (15), 4841-4849.

Sato, S. I.; Nam, J. W.; Kasuga, K.; Nojiri, H.; Yamane, $\mathrm{H}$. and Omori, T. $\left(1997^{\mathrm{b}}\right)$, Identification and Characterization of Genes Encoding Carbazole 1,9aDioxygenase in Pseudomonas sp. Strain CA10. J. Bacteriol., 179 : (15), 4850-4858.

Shepherd, J. M. and Lloyd-Jones, G. (1998), Novel Carbazole Degradation Genes of Sphingomonas CB3: Sequence Analysis, Transcription, and Molecular Ecology. Biochem. Biophys. Res. Commun., 247 : (1), 129-135.

Received: September 29, 2004; Revised: February 25, 2005; Accepted: March 25, 2005. 